\title{
Use of feed additives in animal agriculture: gut response in broilers
}

${ }^{1}$ Ofongo - Abule, R. T. S. and ${ }^{2}$ Etebu, E.

${ }^{\prime}$ Department of Animal Science, Niger Delta University

${ }^{2}$ Molecular Genetics/Microbiology Research Unit, Department of Biological Sciences,

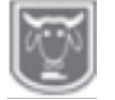

Niger Delta University, Wilberforce Island, Bayelsa State - Nigeria

Corresponding author: tariruth@live.de;

Abstract

phone: $08158683316 ; 08038827764$

$\overline{\text { Feed additives such as enzymes, probiotics, prebiotics and acidifiers are few examples of }}$ suitable alternatives to in-feed antibiotics in animal agriculture due to the ban of antibiotic use. However, the Nigerian poultry industry still experiences cases of antibiotic use. The gut benefits of alternatives to antibiotics often culminate in improved growth performance but there are or may be certain gut responses that attribute to the observed performance of poultry birds. In order to ascertain this, an experiment was conducted to evaluate the effect of antibiotic administration and enzyme supplementation on gut $\mathrm{pH}$ and bacteria counts. One hundred and fifty day-old broiler chicks were randomly distributed to three dietary treatments having five replicates and 10 birds per replicate. The experiment lasted forty-two (42) days and was arranged as a completely randomized design. A maize-soybean meal diet not supplemented with antibiotic or enzyme served as the control. Birds fed diet II had antibiotic (Dicoxin plus ()) administered to them. Birds fed diet III had their diets supplemented with enzyme (Roxazyme $G 2 G \AA)$ ). Results indicated $p H$ of the crop to be significantly $(P<0.01)$ reduced by feed additive. The $p H$ of the Ileum was least (5.65) under antibiotic administration but was not significantly different $(p>0.05)$ different that of birds fed control and enzyme supplemented diet. Gizzard $p H$ was acidic but not significantly $(P>0.05)$ across all the treatments. Lactobacillus and Coliform counts were significant $(P<0.05)$ affected by feed additive addition. It can be concluded that feed additive impact on gut pH can influence the type and population of bacteria present in the gastrointestinal tract.

Keywords: gut $p H$, antibiotics, enzymes, gut bacteria, broilers

\section{Introduction}

The micro flora and digestive physiological parameters such as intestinal enzymes, $\mathrm{pH}$, viscosity, histo - morphological structures of intestine plays a major role in production performance of broilers. Broiler chickens are reared up to $35-42$ days of age in intensive system, where the birds are subjected to many types of stress that can result in reduced performance. To alleviate these types of stress, antimicrobials have been used as feed supplement for more than 50 years in poultry feed. Most of the antibiotic growth promoters act by modifying the intestinal flora, which are associated with poor health and reduced performance of animals (Bedford, 2000). Digesta $\mathrm{pH}$ is one of the major gastrointestinal environment influences on nutrient biodiversity (Shafey et al., 1991). Accurate determination of digesta $\mathrm{pH}$ in broilers could act as a tool to indicate potential for optimum gut health and hence maximize nutrient absorption (Morgan et al., 2012). Lower digesta $\mathrm{pH}$ in the gut is associated with a reduction in growth and colonization by pathogenic organisms thus permitting greater partitioning of nutrient for optimal growth and nutrient utilization. Consequently, lower gut $\mathrm{pH}$ could be associated with higher weight gain Dono et al. (2014). Lower $\mathrm{pH}$ in the intestine 
inhibits the growth of especially pathogenic organism and favors growth of beneficial organism as reported by Andil et al. (2011). Removing digesta appears to negatively affect the accuracy of digesta $\mathrm{pH}$ reading (Morgan et al., 2012). Previous investigations using mainly culturedependent approach showed that majority of Lactobacilli, Enterococci and Clostridia were found in the gut of broiler birds (Salanitro et al., 1978; Barnes, 1979; Mead, 1989; Engberge et al., 2000). The micro flora is believed to protect against intestinal colonization by pathogens and are primarily responsible for degrading the copious amount of mucus produced by goblet cells in the intestine. Many factors can affect the composition of the avian bacterial community such as diet, age, antibiotic administration and infection of pathogenic organisms (Lu et al., 2003). Bacteria within the gut microbial community interact with each other as well as their host (De-Agelis et al., 2006; Kelly et al., 2005). Microorganisms can directly interact with the lining of the gut and immunological status of birds (Torok et al., 2007). The $\mathrm{pH}$ concentration of digesta collections from different segment of the gut of broilers was observed that most organic acid used in feed and drinking water are absorbed by the upper gastrointestinal segment i.e. crop, pro ventriculus and gizzard and only a little portion of organic acid get to the lower digestive tract - caecum (Hummel et al., 1993). In the past years, a great deal of interest has been generated on the evaluation of the alternative means for manipulation of gastrointestinal micro flora in livestock production. Hinton et al., (1990) explained that the crop contains some microbes which produce lactic acid that helps to decrease crop $\mathrm{pH}$. This study was designed to determine the effect of antibiotics and enzyme supplementation on gut $\mathrm{pH}$ and also to determine the intestinal microbial counts in broilers as affected by gut $\mathrm{pH}$.

\section{Materials and methods Animal experiment}

A total number of 150 one-day old (ANAC 2000) broiler chicks were utilized in this study. The chicks were brooded together for seven days at a temperature of $32^{\circ} \mathrm{C}$. The birds were randomly distributed into three dietary treatments having five replicates of 10 birds per replicate. The diet consisted of maize - soybean meal (M-SBM) as main ingredient which served as control diet. Birds fed diet 2 was given the same diet with the control but were administered antibiotics at an inclusion rate of $100 \mathrm{gm} / 160$ litres in drinking water. The third diet was also the same as the control diet but was supplemented with a non starch polysaccharide degrading enzyme (Roxazyme G2G ${ }^{\circledR}$ ). The birds were fed ad libitum and the experiment lasted 35 days.

\section{Gut pH determination}

On day 35, two birds per replicate were slaughtered by cervical dislocation to enable collection of digesta content of the crop, gizzard, ileum and both ceca. Digesta collected was utilized for $\mathrm{pH}$ determination with a $\mathrm{pH}$ meter (Model: HANNA Instrument - Hi 9024-microcomputer $\mathrm{pH}$ meter). The experimental diet was collected for each treatment and set aside for proximate analysis according to AOAC (1990).

\section{Determination of gut micro flora}

Sodium Chloride $(\mathrm{NaCl})$, de Man Rogosa and Sharp (MRS) agar and McConkey agar was prepared and sterilized for $121^{\circ} \mathrm{C}$ in an autoclave, and timed for 15 minutes. The $\mathrm{NaCl}$ and agars were removed after sterilization and allowed to cool. The $\mathrm{NaCl}$ $(9 \mathrm{ml})$ was poured into six test tubes 


\section{Ofongo - Abule and Etebu}

respectively and 1 gm wet weight of digesta collected from the ileum was added into the first test tube for serial dilution, a sterilized pipette was used to mix properly. The diluents in the fourth, fifth and sixth test tubes were plated out on MRS and McConkey agar in triplicates respectively. The petri dishes were kept upside down in an incubator $\left(30^{\circ} \mathrm{C}\right.$ on MRS agar for 48 hours to determine Lactobacillus and $37^{\circ} \mathrm{C}$ on McConkey agar for 24 hours to determine Coliform). Colony growth was counted and values obtained were log transformed before carrying out statistical analysis using SPSS volume 17 and significant means separated using duncans multiple range test.

Table 1: Gross and nutrient composition of experimental diets (all units in Kg except where indicated)

\begin{tabular}{lccc}
\hline Feed ingredient & M - SBM & $\mathrm{M}-\mathrm{SBM}+\mathrm{AB}$ & $\mathrm{M}-\mathrm{SBM}+\mathrm{EZ}$ \\
\hline Maize & 55 & 55 & 55 \\
SBM & 32.5 & 32.5 & 32.5 \\
Fish meal & 4.0 & 4.0 & 4.0 \\
Cassava starch & 4.2 & 4.2 & 4.2 \\
Constant ingredients* & 4.3 & 4.3 & 4.3 \\
Total & 100 & 100 & 100 \\
Analysed & & & \\
composition (g/kgDM) & & 733.5 & 651.5 \\
Dry matter (grams) & 739.5 & 203.1 & 170.4 \\
Ash & 254.2 & 229.0 & 256.3 \\
Protein & 238.0 & 62.7 & 49.1 \\
Ether extract & 58.1 & 73.6 & 70.6 \\
Crude fibre & 64.9 & & \\
\hline
\end{tabular}

*: Bone meal: 2.1 kg; Oyster shel: 1.0kg; Vitamin/premix: 0.25kg, DL-Methionine: $0.15 \mathrm{~kg}$, Common salt 0.3kg, $\mathrm{TiO}_{2}: 0.5 \mathrm{~kg}$. SBM: soybean meal

\section{Results and discussion}

\section{Nutrient composition}

Nutrient composition of the experimental diets is presented in Table 1. Although all three experimental diets were similar but there was disparity in analyzed nutrient composition especially crude protein and ash concentration. The ash concentration was least in enzyme supplemented diet $(170.4 \mathrm{~g} / \mathrm{kgDM})$ but high in the control diet $(254.2 \mathrm{~g} / \mathrm{kgDM})$. However, the reverse was the case with regards to crude protein concentration which was least in the diet which antibiotic was administered $(229.0 \mathrm{~g} / \mathrm{kgDM})$ but high in the enzyme supplemented diet $(256.3 \mathrm{~g} / \mathrm{kgDM})$. Dry matter concentration was least in $\mathrm{M}$ - SBM $+\mathrm{EZ}$ diet $(651.5 \mathrm{~g})$ compared to the control (739.4g) and antibiotic (M - SBM +AB) administration $(733.5 \mathrm{~g})$.

\section{GutpH}

Gut $\mathrm{pH}$ as affected by antibiotic administration and enzyme supplementation is presented in Table 2 . Antibiotic administration and enzyme supplementation had significant $(\mathrm{p}<0.01)$ on $\mathrm{pH}$ of the crop. Values recorded were more acidic with a value of 4.83 recorded for antibiotic administration and 5.09 for enzyme supplementation.

Table 2: Effect of antibiotic administration and enzyme Supplementation on gut pH in broilers

\begin{tabular}{lrcccc} 
Gut Section & $\mathrm{M}-\mathrm{SBM}$ & $\mathrm{M}-\mathrm{SBM}+\mathrm{AB}$ & $\mathrm{M}-\mathrm{SBM}+\mathrm{EZ}$ & SEM & P Value \\
\hline Crop & $6.02^{\mathrm{b}}$ & $4.83^{\mathrm{a}}$ & $5.09^{\mathrm{a}}$ & 0.04 & $0.008^{* *}$ \\
Gizzard & 5.59 & 5.45 & 4.91 & 0.20 & $0.375^{\text {ns }}$ \\
Ileum & 6.46 & 5.65 & 6.10 & 0.18 & $0.215^{\text {ns }}$ \\
Caecum & 6.66 & 6.59 & 6.52 & 0.07 & $0.770^{\text {ns }}$
\end{tabular}

ab: means along the same row with different superscripts are significantly different $(p<0.05)$

${ }^{* *}: 1 \%$ level of significant difference. 
Gut $\mathrm{pH}$ gradually increased from highly acidic to near neutral from the crop to the caecum in birds administered antibiotics. However, this was not the case in the gut of broilers fed the control and enzyme supplemented diets. The $\mathrm{pH}$ value dropped in the gizzard in broilers fed the control diet from 6.02 in the crop to 5.59 and 5.09 in the crop to 4.91 in broilers fed enzyme supplemented diet. In all, $\mathrm{pH}$ values recorded for the respective gut segments in broilers fed enzyme supplemented and antibiotics administered birds was lower compared to the control but was not significantly different $(p>0.05)$ across the treatments with regards to values recorded in the gizzard, ileum and caecum.

Table 3: Effect of antibiotics administration and enzyme supplementation on gut microflora counts isolated from the ileum of broilers

\begin{tabular}{llllll}
\hline Bacteria & M-SBM & M-SBM+AB & M-SBM+EZ & SEM & P value \\
\hline Lactobacillus spp & $7.58^{\mathrm{ab}}$ & $7.33^{\mathrm{b}}$ & $7.76^{\mathrm{a}}$ & 0.06 & $0.034^{*}$ \\
Coliform & $7.81^{\mathrm{b}}$ & $7.67^{\mathrm{b}}$ & $8.27^{\mathrm{a}}$ & 0.06 & $0.003^{* *}$ \\
\hline ab: means along the same row with different superscripts are significantly different $(\boldsymbol{p}<\mathbf{0 . 0 5})$. & &
\end{tabular}

${ }^{*}: 5 \%$ level of significant, ${ }^{* *:}: 1 \%$ level of significant difference.

\section{Gut microflora counts}

Table 3 showed that enzyme supplementation significantly $(p<0.05)$ increased Lactobacillus counts in the ileum while antibiotic administration significantly $(p<0.05)$ reduced Lactobacillus counts. It was observed that Coliform counts was significantly $(p<0.01)$ higher in the ileum of birds fed enzyme supplemented diet (8.27) compared to the control (7.81) and antibiotic administration (7.67) which recorded significantly $(p<0.01)$ lower values respectively.

Enzymes have tendency to increase crude protein of a diet because certain protein attached to carbohydrate molecules are released when such carbohydrate molecules are hydrolyzed by enzymes (Ofongo - Abule and Ohimain, 2016). According to Dono et al. (2014), lower digesta $\mathrm{pH}$ was associated with birds of high body weight irrespective of the phase (starter or grower or finisher). The high weight group in that study recorded a significantly lower proventriculus (gizzard) $\mathrm{pH}$ compared to a low weight group. This was also the case in this study. Birds fed enzyme supplemented diet had the least proventriculus $\mathrm{pH}$ and a significantly high weight gain (unpublished data).

A lower crop $\mathrm{pH}$ was observed due to antibiotic administration and enzyme supplementation. This is in line with an earlier report by Hinton et al. (1990) which stated that the crop contains some microbes (mostly Lactobacillus) which produce lactic acid that ultimately helps to decrease $\mathrm{pH}$ of the crop. However, the report of Hummel et al. (1993) differed from this in that the author reported an increase in crop $\mathrm{pH}$. The methodology of $\mathrm{pH}$ determination may play a role in gut $\mathrm{pH}$ values recorded as stated by Morgan et al. (2012). Ofongo Abule et al. (2016); who reported an acidic $\mathrm{pH}$ in the gut of broilers as resulting from the effect of diet type and enzyme supplementation. The authors recorded a gradual increase in gut $\mathrm{pH}$ from crop to ileum and eventually caecum. This trend was also observed in the current study in exception of $\mathrm{pH}$ value recorded in the gizzard of birds fed enzyme supplemented diet which was numerically low (4.91) or more acidic compared to values recorded in control and antibiotic administration. Furthermore, the report of Olukosi and Dono (2014) indicated that phytobiotic 
supplementation (turmeric and garlic meal) at $10 \mathrm{~g} / \mathrm{kg}$ of diet significantly reduced digesta $\mathrm{pH}$ in the crop, proventriculus and caeca but had no effect at the jejunum. Invariably digesta $\mathrm{pH}$ response may differ with additive supplemented to diets of similar ingredient composition. Although in - feed antibiotic use is banned in certain countries, however gut micro flora response to antibiotic use may differ when compared to other available alternatives. Gut micro flora response in this study indicated a significant $(p<0.05)$ increase of Lactobacillus spp in ileum of birds fed enzyme supplemented diet. However, that recorded for the control diet was higher than the value recorded in birds administered antibiotic but was not significantly different $(p>0.05)$. Based on $\mathrm{pH}$ values recorded in the ileum, it would have been expected that lactobacillus counts would be higher in antibiotic administered diet than control or enzyme supplemented diet. According to Gadd (1997), antibiotics affect micro flora by altering the metabolism of microorganisms and suppressing microbial growth in the gut. This was also stated by Jones and Ricket (2003) that antibiotics decrease microbial load in the GIT and improve weight gain and feed conversion ratio thereby making more nutrients available to the host. According to Ohimain and Ofongo (2013) the stimulation of Lactobacillus by a diet containing wheat offal with or without enzyme supplementation coincided with the reduction in coliform and Escherichia coli population. This observation was not the case in the current study but the least count of coliform was recorded in antibiotic treatment. The individual variability in body weight and nutrient utilization in grower and finisher phases of broilers can be partly explained by variability in jejuna and caecal pH (Dono et al., 2014). Also this may be related to the type of microbes colonizing the gastro intestinal tract which will ultimately affect bird performance

\section{Conclusion}

The study showed that antibiotic administration and enzyme supplementation lowers gut $\mathrm{pH}$ while Lactobacillus count was increased by enzyme supplementation.

\section{References}

Adil, S. Banday, M. T.; Bhat, G. A., Qureshi, S. D. and Wani S. A. 2011. Effect of supplemental organic acids on growth performance and gut microbial population of broiler chicken. Livestock Research for Rural Development. Volume 23, Article \#6. Retrieved July 25, 2016, from http://www.lrrd.org/lrrd23/1/adil23 006.htm

A.O. A. C 1990. Official methods of analysis, 15th ed. Association of Official Analytical Chemists, Dc.

Barnes, E. M. 1979. The intestinal micro flora of poultry and game birds during life and after storage. J. Appl. Microbiology, 46(3):407-419.

Bedford, M. R. 2000. Removal of antibiotic growth promoters from poultry diet implications and strategies to minimize subsequent problems. World's Poult. Sci. J., 56:347-365.

De Angelis, M., Siragusa, S., Berloco, M., Caputo, L., Settanmi, L., Alfonsi, G., Amerio, M., Grandi, A., Ragni, A. and Gobbetti, M. 2006. Selection of potential probiotic lactobacilli from pig feces to be used as additives in pelleted feeding. Research in Microbiology 157(8): $792-801$. 
Dono, N. D., Sparks, N. H. and Olukosi, O. A. 2014. Association between digesta $\mathrm{pH}$, body weight and nutrient utilization in chickens of different body weights and at different ages. The Journal of Poultry Science 51: $180-184$.

Engberge, R. M., Hedemann, M. S., Leser, T. D. and Jensen, B. B. 2000. Effect of zinc bacitracin and salinomycin on intestinal micro flora and performance of broilers. Poult. Sci. 79(9):1311-1319

Hinton Jr. A., Corner, D. E., Spates, G. E., Norman, J. O., Ziprin, R. L, Beier, R. C. and Deloach, J. R. 1990. Biological control of Salmonella typhimurium in young chickens. Avian Disease 34: 626 633.

Hummel, R., Tschape, H. and Witte, W. 1986. Spread of plasmid mediated nourseothricin resistance due to antibiotic use in animal husbandry. Journal of Basic Microbiology 26(8): $461-466$.

Lu, J., Idris, U., Harman, B., Hofacre, C., Maurer, J. J. and Lee, M. D. 2003. Diversity of the intestinal bacterial community of the maturing broiler chicken. Applied and Environmental Microbiology 69 (11):6816-6824.

Jones, F. T. and Ricke, S. C. 2003. Observations on the history of the development of antimicrobials and their use in poultry feeds. Poult. Sci. 82: 613-617.

Kelly, D., Conway, S. and Aminov, R. 2005. Commensal gut bacteria: Mechanisms of immune modulation. Trends Immunol. 26: $326-333$.

Mead, G. C. 1989. Microbes if the avian cecum: Types presents and substrates utilized. Journal of Experimental zoology, volume 252 (3): $48-54$.

Morgan, N. K., Walk, C. Bedford, M. R. and Burton, E. J., 2012. Optimum methodology for determining broiler gastrointestinal $\mathrm{pH}$. In proceedings: WPSA, BSAS annual Conference, Nottingham University. Pp 10.

Ohimain, E. I. and Ofongo, R. T. S. 2013. Effect of enzyme supplemented diet on gut microflora, digesta $\mathrm{pH}$ and performance of broiler chickens. Journal of microbiology biotechnology and food sciences 3 (2) 127-131

Ofongo - Abule, R. T. S.; Etebu, E. and Ohimain, E. I. 2016. Effect of diet type and enzyme supplementation on gut $\mathrm{pH}$ in broilers. International Journal of Agriculture Innovations and Research 4(5): $964-967$.

Ofongo-Abule, R. T. S. and Ohimain, E. I. 2016. Enzyme supplemented wheat offal diet improves performance of broilers. International Journal of Agriculture Innovations and Research 4(5): 968 -971 .

Olukosi, O. A. and Dono, N. D. 2014. Modification of digesta $\mathrm{pH}$ and intestinal morphology with the use of benzoic acid or phytobiotics and the effects on broiler growth performance and nutrient utilization. Journal of Animal Science, 92: 3945-3953.

Salanitro, J. P., Blake, I. G., Muirehead, P. A., Maglio, M. and Goodman, J. R. 1978. Bacteria isolated from the duodenum, ileum, and cecum of young chicks. Appl. Environ. Microbiol. 35(4): $782-790$.

Shafey, T. M., Mcdonald, M. W. And 
Dingle, J. G. 1991. Effects of dietary calcium and available phosphorus concentration on the availability of calcium, iron, magnesium and zinc from the intestinal contents of meat chickens. British Poultry Science 32(1): 185 194.
Torok, V. A., Ophel-Keller, K., Loo, M. and Hughes, R. J. 2008. Application of methods for identifying broiler chicken gut bacterial species linked with increased energy metabolism. Appl. Environ. Microbiol. Vol 74 (3): 783 $-791$.

Received: $15^{\text {th }}$ November, 2017

Accepted: $17^{\text {th }}$ February, 2018 